\title{
ALEKSANDER LEDNICKI I LOS JEGO ŚRODOWISKA, POLONII W ROSJI, NA PRZELOMIE XIX I XX WIEKU \\ JAKO ZWIERCIADŁO PRZEMIAN \\ POLSKIEGO POLA WLADZY
}

WPROWADZENIE

W

niniejszym artykule chciatbym przybliżyć obraz relatywnie zapomnianego środowiska rosyjskiej Polonii z końca XIX i początku XX wieku i rozważyć jego pozycję w kontekście ewoluujących na przestrzeni minionego stulecia struktur społeczeństwa polskiego. Chodzić mi tu będzie przede wszystkim o środowiska liberalne związane z kręgami bogatszego polskiego ziemiaństwa i rodzącej się burżuazji z terenów Imperium Rosyjskiego. Są to kręgi, dla których rewolucja październikowa 1917 r. okazała się śmiertelnym ciosem prowadzącym do nieuchronnej dezintegracji przypieczętowanej w roku 1944 oraz do stopniowego zaniku z polskiej pamięci narodowej głównego nurtu. W ich efekcie w dyskursach głównego nurtu historii polskiej $w$ odniesieniu do ziem pod panowaniem rosyjskim na plan pierwszy wysuwają się nazwiska inteligentów, w szczególności tych, którzy zaangażowani byli w aktywną walkę z caratem lub bolszewikami. Znane są też nazwiska wielu Polaków zaangażowanych w ruchu rewolucyjnym, które spopularyzowano szczególnie w okresie istnienia PRL. W niniejszym tekście chciałbym upomnieć się o zwrócenie większej uwagi na pomijane zwykle w głównym nurcie debat historycznych środowiska rosyjskiej Polonii o orientacji liberalnej, bliższe ziemiaństwu i rodzącej się burżuazji. Ich symbolem będzie tu postać Aleksandra Lednickiego, wybitnego działacza polskiego w Rosji, polityka i znanego moskiewskiego adwokata. W odniesieniu do jego sylwetki wskazywać będe próbowat na prawdopodobne główne uwarunkowania relatywnej

Dr hab. Tomasz ZARYCKI jest profesorem nadzwyczajnym na Uniwersytecie Warszawskim i dyrektorem Instytutu Studiów Społecznych im. Roberta B. Zajonca (ISS UW). t.zarycki@uw.edu.pl 
marginalizacji we współczesnej wizji historii Polski na przełomie wieków liberalnych środowisk ziemiańsko-mieszczańskich o orientacji pojednawczej względem Imperium Rosyjskiego.

Jak się wydaje, do jednych z ważniejszych pośród owych uwarunkowań należy dominujący wciąż negatywny obraz Rosji jako znaczącego obcego dla tożsamości polskiej, źródło stałego zagrożenia jednoczącego Polaków (Zarycki 2004). Rosja wpisuje się w dominujących w Polsce dyskursach w klasyczne schematy tzw. "orientalizmu”, a więc opisywanego przez Edwarda Saida syndromu patrzenia na szeroko rozumiane kraje wschodnie jako zacofane, niższe cywilizacyjnie i będące źródłem niebezpieczeństwa (Said 2005). Z tego względu w polskiej percepcji Rosji, a także historii stosunków polsko-rosyjskich wydaje się przejawiać jednostronność związana z tendencją do eksponowania cech negatywnych Rosji, postrzegania ich jako immanentnych i trwałych, podkreślania cierpień doznanych przez Polaków z rąk rosyjskich i pomijania pozytywnych czy też neutralnych aspektów interakcji pomiędzy przedstawicielami obu narodów (Zarycki 2008b). Charakterystyczne dla tej tendencji jest także dość powszechne utożsamianie Rosji przedrewolucyjnej z Rosją Sowiecką i postrzeganie ich jako równie barbarzyńskich oraz nieprzyjaznych Polsce. Sztandarowym dla takiej percepcji Rosji ujęciem jej dziejów jest znane dzieło Jana Kucharzewskiego pt. „Od białego do czerwonego caratu” (Kucharzewski 1923). Czynniki te powodują, że trudniej dziś dowartościować w narracji historycznej środowiska polskie silniej zintegrowane w ramach systemów politycznego i ekonomicznego ówczesnej Rosji. Można jednocześnie argumentować, że problem ten ze względu na dominację wartości narodowowyzwoleńczych we współczesnych polskich dyskursach historycznych dotyczy wszystkich państw zaborczych w elitach, w których znalazło się wielu Polaków, a pamięć o których jest dziś zwykle nikła.

Szczególnie jednak wspomniana tendencja do negatywnego postrzegania Rosji w polskiej historiografii wydaje się owocować nikłym zainteresowaniem losami Polaków aktywnie uczestniczącymi w jej życiu politycznym czy społecznym, a nie będących ewidentnie jej ofiarami czy zadeklarowanymi wrogami, na przykład powstańcami, zesłańcami czy wywłaszczonymi ziemianami (Tazbir 2003). Wśród Polaków pracujących twórczo w Rosji relatywnie lepiej znana jest spuścizna polskich naukowców działających w Imperium Rosyjskim, szczególnie tych którzy eksplorowali bezkresne obszary Syberii, jak np. Bronisława Piłsudskiego, Aleksandra Czekanowskiego, Jana Czerskiego czy Benedykta Dybowskiego. Ich swoistym „atutem” pozwalającym na zachowanie pewnej „widoczności" we współczesnym dyskursie historycznym głównego nurtu jest jednak to, że większość z nich była także zesłańcami politycznymi. Są oni jednocześnie symbolicznymi, a w niektórych przypadkach i biologicznymi, przodkami dzisiejszej inteligencji, którą jak się wydaje można uważać za warstwę dominującą we współczesnej Polsce. O wiele słabiej znane są natomiast postacie działaczy politycznych i społecznych a także gospodarczych, którzy pozostając przy polskiej tożsamości narodowej, aktywnie uczestniczyli w życiu Imperium, odnosząc w jego ramach nierzadko znaczne sukcesy, nie wchodząc jednocześnie w otwartą konfrontację z jego władzami.

Oczywiście nie wszystkie z tych osób mogą dziś służyć za wzorce patriotyzmu czy innych cnót. Nierzadko osoby te rozdarte były w swych karierach i działalności pomiędzy tożsamością polską a rosyjską, pomiędzy lojalnością wobec różnie pojmowanej polskości a lojalnością wobec państwa rosyjskiego. Stawali oni często przed koniecznością wyborów, dokonywania kompromisów koniecznych dla osiągania pozycji społecznej czy stanowisk w instytucjach publicznych i zachowania szacunku w środowiskach polskich, uznania 
dla ich patriotyzmu. Ich biografie łączące nierzadko wspaniałe osiągnięcia w różnych wymiarach, z wieloma momentami trudnymi, porażkami, decyzjami życiowymi powszechnie w polskich środowiskach odbieranymi negatywnie, czy nawet prowadzącymi do wykluczenia ze społeczności polskiej, wydają się jednak godne uwagi z wielu względów. Sam zaś fakt rozproszenia się omawianego środowiska i zaniku o nim pamięci w głównych nurtach polskiej historiografii wydaje się być świadectwem kluczowych przemian struktury polskiego społeczeństwa, na które chciałbym zwrócić uwage w niniejszym tekście.

\section{KONTEKST SCENY POLITYCZNEJ PRZELOMU WIEKÓW}

Przypomnijmy więc podstawowe uwarunkowania polityczne okresu kluczowej transformacji układu sił w polskim polu politycznym. Jak podsumowuje Zenowiusz Ponarski (Ponarski 2003), w pierwszych latach XX wieku mówić można było o trzech głównych nurtach polskich organizacji politycznych w Rosji. Były to: po pierwsze - stara emigracja polska, zarówno liberalno-lewicowa jak i konserwatywna. Znacząca czéść jej przedstawicieli na czele z samym Aleksandrem Lednickim przejawiała tendencję do współpracy z liberalną, mieszczańską opozycją rosyjską, w szczególności kadetami (Partią Konstytucyjno-Demokratyczną, mającą najliczniejszą reprezentację w I Dumie), eserami (Partią Socjalistów-Rewolucjonistów, której członkiem był m.in. Aleksander Kiereński), niekiedy nawet mienszewikami. Nurt odmienny stanowili tzw. „realiści” uznający za jedynego wiarygodnego partnera politycznego w Rosji władze, tzn. autokratyczną elite Imperium. Głównym reprezentantem tej orientacji była Narodowa Demokracja, a jej szeregi zostaty silnie w Rosji wzmocnione po wybuchu I wojny światowej, gdy do Moskwy i innych miast rosyjskich napłynęli liczni polscy uchodźcy wojenni, głównie z terenów Kongresówki. Trzecia orientacja to tzw. lewica niepodległościowa, z PPS na czele, początkowo o orientacji proaustriackiej. Wspomnieć można także o lewicy komunistycznej, zorientowanej na współpracę z bolszewikami, która nie odgrywała jednak znaczącej roli wśród ówczesnej rosyjskiej Polonii.

W wyniku I wojny światowej spośród wspomnianych tu orientacji polskich w Rosji pierwsza odniosła porażkę najbardziej dramatyczną. Przestała bowiem istnieć dotychczasowa Rosja, a w szczególności unicestwione zostały, w znacznym stopniu fizycznie, a częściowo wygnane, jej liberalne i mieszczańskie elity będące głównym partnerem politycznym obozu reprezentowanego przez Lednickiego. Co więcej, podcięte zostały całkowicie podstawy statusu a czasem i materialnej egzystencji tej grupy. Część zginęła już w pierwszych latach z rąk bolszewickich, wszyscy stracili większość swoich majątków, jako że ulokowane były one na terenach, które od początku weszły w skład Rosji Sowieckiej. Względną porażkę poniósł też obóz endecki stawiający na carat jako partnera dialogu politycznego. Nie była jednak to porażka oznaczająca całkowitą dezintegrację jak w przypadku liberałów. Dla endecji władze carskie były tylko taktycznym sojusznikiem, a jednocześnie nie reprezentowała ona środowisk związanych tak silnie z dotychczasowym rosyjskim systemem społeczno-gospodarczym. Jednocześnie Dmowski w okresie odradzania się państwa polskiego uzyskał znaczącą przewagę polityczną poprzez zdobycie statusu głównego reprezentanta interesów polskich wobec mocarstw zachodnich. To zachodnie uznanie, którego nie zdołał uzyskać lojalniejszy wobec republikańskiej Rosji Lednicki, było niezwykle istotnym czynnikiem przechylającym na niekorzyść tego ostatniego 
rozkład sił na scenie politycznej nowej II Rzeczypospolitej. Głównym zwycięzcą przemian polityczno-własnościowych w omawianym okresie, także w warstwie symbolicznej, okazała się przede wszystkim lewica. Dowartościowana została zarówno lewica niepodległościowa jak i komunistyczna, choć okresy ich głównych triumfów były jak wiadomo nieco inne. Pierwsza cieszyła się największymi wpływami w okresie międzywojennym, druga zaś w okresie po 1944 r.

Można by więc powiedzieć, że wydarzenia lat 1917-1920 potwierdziły niejako zasadność wizji, wedle których Rosja w żadnej swojej inkarnacji nie może być partnerem Polski, czy też następnie poglądów komunistycznych, według których jedynym uzasadnionym wyborem dla Polski było dołączenie do bolszewickiego ruchu rewolucyjnego, jako predystynowanego przez historię lidera przemian społecznych na świecie. Pogląd o nieuchronności upadku republikańskiej, liberalnej Rosji wydaje się jednak założeniem dość arbitralnym. Warto jednocześnie zwrócić uwage na jego fundamentalne znaczenie we współczesnym polskim dyskursie historycznym głównego nurtu, którego ważną rolą jest także legitymizacja dominujących sposobów myślenia o strategicznych wyborach Polski na arenie międzynarodowej. Dominujące dziś w Polsce odczytanie historii Rosji prowadzi zwykle do konkluzji, iż jest ona nieuchronnie skazana na autokratyczny system polityczny w takim czy innym wydaniu. Znacząco ogranicza ono spektrum wyobrażalnych wizji przyszłości tego kraju, a w konsekwencji także wizji relacji pomiędzy Polską i Rosją. Jak każde odczytanie historii, wydaje się ono jednak znacząco jednostronne i silnie uzależnione od dominujących na scenie politycznej wizji polskiej doktryny polityki międzynarodowej.

\section{INTERPRETACJA PRZEMIAN SPOLECZEŃSTW POLSKI I ROSJI INSPIROWANA TEORIĄ PIERRE'A BOURDIEU}

Na ówczesny kontekst podziałów w polskim społeczeństwie zaboru rosyjskiego można także spojrzeć w ujęciu nieco innym od ściśle politycznego czy też geopolitycznego. W tym celu użyteczne będzie odwołanie się do pojęcia "pola władzy" wprowadzonego do literatury socjologicznej przez znanego socjologa Pierre'a Bourdieu (Bourdieu, Wacquant, 1993). Pole władzy jest w rozumieniu Bourdieu strukturą określającą logikę organizacji klas wyższych $w$ danym społeczeństwie. Jego podziały generują fundamentalne osie opozycji organizacji społecznej i są przenoszone na wszystkie inne pola, w tym pole polityczne, kulturowe czy ekonomiczne, a także szereg pomniejszych mniej lub bardziej autonomicznych pól takich jak pole religijne, pole mediów, literatury czy sztuki. Jak pokazuje Bourdieu w swoich licznych pracach, w tym w stynnej "Dystynkcji" (Bourdieu, 2006), pole władzy współczesnych społeczeństw zachodnich dzieli się zwykle według fundamentalnej opozycji pomiędzy kapitałem ekonomicznym a kapitałem kulturowym. Odpowiada ona współzawodnictwu między elitą ekonomiczną a elitą kulturową, w której ta ostatnia ma w społeczeństwach zachodnich zwykle charakter podporządkowany. Innymi słowy, pozostając ważnym aktorem w polu władzy, ma jednak w nim pozycję zależną, co czyni zeń według słów Bourdieu słabszego partnera elity ekonomicznej we wspólnej dominacji nad pozostałą częścią społeczeństwa.

Można zwrócić uwagę, iż druga połowa XIX wieku była okresem kształtowania się tego, co można by nazwać protopolem władzy społeczeństwa polskiego. Kluczowe procesy w tym zakresie zachodziły w zaborze rosyjskim, w którym między innymi miały miej- 
sce dwa najważniejsze powstania: listopadowe i styczniowe. Można zwrócić uwagę, że oba z nich, a w szczególności powstanie 1863 r., cechowały się wyraźną logiką napięcia społecznego, którą odczytywać można w kategoriach napięcia pomiędzy tym co Bourdieu nazywa ekonomicznym i kulturowym biegunami pola władzy. W powstaniu styczniowym odpowiadały one partiom Białych i Czerwonych. Warto pamiętać, że grupujące ziemiaństwo, arystokrację i bogate mieszczaństwo stronnictwo Białych do udziału w powstaniu doprowadzone zostało swoistym patriotycznym szantażem Czerwonych. Biali zorientowani byli raczej na prace organiczną, a ich stosunki z władzami Imperium pozostawały zwykle o wiele lepsze niż Czerwonych. W szeregach elity tych ostatnich dominowała drobna i systematycznie marginalizowana w wymiarze ekonomicznym i politycznym szlachta. Dotykał ją zarówno upadek gospodarki folwarcznej, carskie wywłaszczenia, jak też kryzys statusowy związany z pozbawianiem przez władze carskie tytułów szlacheckich. Kolejne powstania antyrosyjskie przyspieszały jednak procesy społeczno-ekonomiczne sprzyjające wzrostowi pozycji drobnej szlachty systematycznie transformującej się w inteligencję. Były one jednocześnie strukturalnie najbardziej kosztowne dla elity rodzącego się pola władzy zorientowanej na kapitał ekonomiczny. To bowiem ziemiańsko-mieszczańskie środowiska traciły najwięcej w wyniku popowstaniowych konfiskat majątków. Utrudniona stawała się także często ich współpraca z administracją rosyjską, w której powstania wzmacniały polityki skierowane przeciw Polakom. Ich istotnym elementem było blokowanie dostępu osobom pochodzenia polskiego do elitarnych i najlepiej płatnych stanowisk administracyjnych. Z drugiej strony, powstania budowały trwałą do dziś legendę rodzącej się inteligencji jako heroicznej elity nowoczesnego społeczeństwa polskiego. Była ona w szczególności w stanie znajdować źródła utrzymania na niższych posadach w administracji Imperium Rosyjskiego. Jak pokazuje przekonująco Andrzej Chwalba (1999), wbrew dominującym stereotypom obecnym wciąż w polskiej historiografii, administracja Królestwa Polskiego była do końca jego istnienia zdominowana przez Polaków, choć trudno dostępne były dla nich stanowiska najbardziej elitarne. Nie prowadzono jednak polityki masowego ich zwalniania ze stanowisk szeregowych (w szczególności z pensjami poniżej 1000 rubli rocznie), na których Polacy dominowali bezwzględnie. W skali Królestwa ich udział w administracji był oczywiście proporcjonalnie mniejszy niż udział Polaków w ludności tzw. Kraju Nadwiślańskiego, jednak na poziomie całego Imperium odsetek Polaków będących na służbie rosyjskiej był znacznie wyższy niż odsetek polskich mieszkańców całego kraju i znacznie wyższy niż odpowiednie wskaźniki w Austro-Węgrzech, a w szczególności w Prusach. Te właśnie liczne szeregi przeciętnie zarabiających urzędników państwowych, nauczycieli czy lekarzy na służbie publicznej tworzyły elity wzmacniającej się systematycznie polskiej inteligencji.

Wspomniane napięcie w rodzącym się polskim polu władzy pomiędzy jego biegunem ekonomicznym i kulturowym, a więc częścią elity opierającą swój status na własnym kapitale ekonomicznym i tą utrzymującą się z posad państwowych oraz wolnych zawodów, trwało w sposób przypominający analogiczne procesy w krajach zachodnich aż do rewolucji październikowej. W kategoriach tej opozycji można też interpretować zasygnalizowane powyżej podziały na ówczesnych scenach politycznych: polskiej i rosyjskiej. Z jednej więc strony lokowały się stronnictwa liberalne i częściowo zachowawcze zorientowane na elity starego i nowego kapitału ekonomicznego odpowiadające bogatemu ziemiaństwu i rodzącej się burżuazji. Z drugiej, rosły w siłę partie inteligenckie, zarówno prawicowe jak i przede wszystkim lewicowe. Reprezentowały one środowiska zorientowane na budowe swojego statusu w kategoriach tego, co Bourdieu nazywa kapitałem kulturowym oraz 
kapitałem społecznym (Bourdieu 1986), ale będące jednocześnie w stanie funkcjonować w polu władzy dzięki dochodom materialnym czerpanym z drobnych posad publicznych, w szczególności urzędniczych. Z racji związku systemu ekonomicznego Imperium Rosyjskiego z jego strukturą państwowo-administracyjną biegun ekonomiczny polskiego protopola władzy zorientowany był o wiele bardziej prorosyjsko niż zaangażowany $w$ działalność narodową biegun inteligencko-kulturowy.

Rewolucją październikowa 1917 burzy tę względną równowagę zarówno w społeczeństwie polskim, jak i rosyjskim. Można zwrócić uwagę, że moment ten był kluczowy dla ustanowienia trwającej do dziś hegemonii szeroko rozumianej inteligencji w polskim polu władzy. Rewolucja bolszewicka oznaczała nagłe podcięcie statusu elit mieszczańskich oraz ziemiańskich, a więc tych, które w takim czy innym wymiarze opierały swój status w pierwszym rzędzie na znaczących zasobach kapitału ekonomicznego. Ich upadek umożliwił wielki polityczny i symboliczny triumf elit inteligenckich, wywodzących się w większości ze zubożałej szlachty. W efekcie środowiska, dla których głównymi zasobami społecznymi były od dawna wykształcenie, "dobre maniery" oraz szeroko rozumiany kapitał społeczny oparty na środowiskowej aktywności, zdominowały polskie życie polityczne, a w konsekwencji również narzuciły swoją wizję hierarchii społecznych, w których kapitał ekonomiczny nie był nigdy zasobem znaczącym. Można zauważyć, iż w momencie swojego odrodzenia po I wojnie światowej Polska redefiniowana jest już jednoznacznie jako państwo zorientowane w pierwszej kolejności na zabezpieczenie interesów inteligenckich, pozbawione zaś w dużym stopniu silnej elity i podmiotowości w wymiarze kapitału ekonomicznego. II Rzeczypospolita tworzy bowiem czy też utrzymuje na wysokim poziomie przyzwoite uniwersytety oraz elitarne szkoły średnie będące kluczowymi ogniwami reprodukcji inteligenckiej elity. Nie jest jednak już w stanie zbudować silnych korporacji, rynków kapitałowych czy banków i utrzymać odziedziczonej po Imperium Rosyjskim elity kapitału ekonomicznego. Ta ostatnia traci nie tylko swój status polityczny, ale przede wszystkim kluczowe zasoby ekonomiczne. Z jednej strony kapitałowe, czego symbolem może być przepadek w 1917 r. większej części kapitałów Banku Handlowego, z drugiej zaś materialne na czele z kluczowymi majątkami ziemskimi pozostałymi poza granica wschodnią II Rzeczypospolitej. Niezwykle wymowną ilustracją degradacji wspomnianych środowisk jest właśnie los Aleksandra Lednickiego i jego środowiska politycznego. Jak się wydaje, pośrednim efektem tych przemian był dodatkowy impuls w kierunku wypierania ze świadomości historycznej, znaczącej w przeszłości roli w dziejach Polski osób operujących w wymiarze kapitału ekonomicznego. Bohaterami polskimi stali się w konsekwencji prawie wyłącznie odwołujący się do inteligenckich ideałów przywódcy polityczni i wojskowi oraz twórcy kultury, a więc liderzy, odpowiednio, pola kapitału społecznego oraz kulturowego. W wymiarze zainteresowań nauki polskiej problem ten zauważa między innymi Ryszard Kołodziejczyk, badacz historii burżuazji, który twierdzi, iż „w pamięci Polaków pionierzy postępu nie cieszą się uznaniem. Nawet po wyjściu z PRL przedsiębiorczość gospodarcza, kreowanie i wyrastanie ludzi interesu znajdują się wyłącznie na marginesie zainteresowań historycznych" (za: Rybak 2010). We współczesnej pamięci o historii politycznej okresu przełomu XIX i XX w. dominującymi aktorami pozostają zaś Piłsudski i Dmowski, operujący głównie w wymiarze logiki politycznej i kulturowej. Związani z interesami ekonomicznymi liberałowie, których dobrym przykładem jest Lednicki, zanikają w niepamięci, która obejmuje także ich zasoby ekonomiczne.

Analogiczne procesy eliminacji elity kapitału ekonomicznego zaszły oczywiście w samej Rosji. Tam jednak w przeciwieństwie do Polski nowe państwo zbudowane zostało 
przez elity inteligenckie o znacząco innej orientacji od elit polskich. Rewolucyjnie zorientowane środowiska inteligenckie zbudowały państwo totalitarne, którego istotę można by opisywać w języku Pierre'a Bourdieu jako hegemonię kapitału politycznego. Wkrótce zniszczyło ono fizycznie nie tylko elity kapitału ekonomicznego, ale także dawne elity kulturowe, tworząc po II wojnie światowej nową inteligencję silnie zależną od państwowej dystrybucji przywilejów (Zarycki, 2008a). Można więc postawić tezę, iż od kluczowego momentu rewolucji październikowej 1917 r., którą oczywiście należy postrzegać jako punkt zwrotny procesów trwających w znacznie szerszym wymiarze czasowym, struktury pól władzy Polski i Rosji po dzień dzisiejszy charakteryzują się fundamentalną odmiennością od typowych pól władzy społeczeństw Europy Zachodniej. Ich specyfika może być definiowana jako marginalizacja logiki kapitału ekonomicznego i jego elity. W przypadku polskim pole władzy i jego logika zostały zdominowane przez elitę i logikę kapitału kulturowego jako jedynego wymiaru względnie stabilnej reprodukcji elit. W przypadku rosyjskim mamy do czynienia z dominacją kapitału politycznego opartą na mechanizmach silnego państwa. Jego elity w Rosji Sowieckiej, znane pod nazwą "nomenklatura”, po dzień dzisiejszy mają znaczną zdolność do wielopokoleniowej reprodukcji i podporządkowania sobie elit kapitału ekonomicznego i kulturowego. Wymownym przykładem tej zależności jest los próbujących uzyskać wpływ na pole polityczne współczesnej Rosji tzw. oligarchów, a więc członków elity kapitału ekonomicznego. Tymczasem w Polsce kapitał ekonomiczny już po 1918 r. jest w znaczącym stopniu kontrolowany przez kapitał zachodni, co nie pozwala na ukształtowanie się silnych rodzimych elit kapitału ekonomicznego zdolnych do utrzymania swojego statusu w dłuższym czasie.

\section{ALEKSANER LEDNICKI JAKO LIDER LIBERALNEJ POLONII ROSYJSKIEJ}

Głównym bohaterem niniejszego tekstu, ilustrującym omawiane procesy przemian polskiego pola władzy, będzie, jak wspomniano, Aleksander Lednicki określany często jako czołowy polityk porozumienia polsko-rosyjskiego przełomu wieków, jeden z głównych liderów polskiej mniejszości w Rosji (tzn. w jej historycznie niepolskich regionach, na czele z Moskwą i Petersburgiem). Lednicki uważany jest zwykle za następcę w swojej roli lidera Polonii zmarłego w 1906 r. Włodzimierz Spasowicza, postaci również dziś w dużym stopniu, pomimo znaczącego dorobku zarówno w wymiarze działalności naukowej jak i społeczno-politycznej, zapomnianej. Na wstępie pozwolę sobie pokrótce przypomnieć życiorys Aleksandra Lednickiego'. Urodził się on 14 lipca 1866 r. w majątku rodzinnym koło Mińska, w polskiej rodzinie ziemiańskiej. Początkowo uczęszczał do rosyjskiego gimnazjum w Mińsku, gdzie kilkakrotnie karany był za posługiwanie się językiem polskim. W 1885 r. w Moskwie rozpoczął studia prawnicze na miejscowym uniwersytecie. Tam angażował się w działalność polskich nieformalnych organizacji studenckich. Stopniowo wchodził też w życie społeczno-politycznej polskiej społeczności w Moskwie, a następnie rosyjskie życie polityczne. Poznał w tym czasie wielu znanych rosyjskich intelektualistów i polityków, by z czasem stać się jednym z najbardziej rozpoznawalnych i wpływowych Polaków w kręgach rosyjskich elit intelektualno-politycznych. W 1887 r. został relegowany z Uniwersytetu Moskiewskiego za udział w demonstracji, w wyniku

\section{.......}

Użyteczny biogram Aleksandra Lednickiego, z którego korzystałem, opracował Andrew Kier Wise, Aleksander Lednicki. A Pole among Russians, a Russian among Poles. Polish-Russian Reconciliation in the Revolution of 1905 (East European Monographs; Boulder: East European Monographs, 2003) viii, s. 230 . 
której zamknięta na semestr została także cała uczelnia. Ostatecznie Lednicki ukończył studia w Jarosławiu i w 1889 r. wrócił do Moskwy, by ożenić się Marią Odlanicką-Poczobutt Kriwonosow. Wielu niechętnych Lednickiemu rodaków opisywało ją w celu pogorszenia jego wizerunku jako Rosjankę. W 1890 r. Lednicki został sekretarzem powstałego wówczas Katolickiego Stowarzyszenia Pomocy Wzajemnej w Moskwie, zaś w 1896 r. wybrany został na jego prezesa. Lednicki angażował się stopniowo coraz bardziej w życie społeczno-polityczne, a jego obszerny dom w Moskwie stał się centrum polskiego życia kulturalnego. Jednocześnie dość szybko po ukończeniu studiów był znany jako wzięty adwokat, co pozwoliło mu stać się człowiekiem majętnym. Zasoby finansowe umożliwiły mu szeroką działalność filantropijną; wspieranie wielu inicjatyw społecznych, w tym dobroczynnych i edukacyjnych, oraz politycznych. Był zaangażowany zarówno w działalność licznych polskich, jak i rosyjskich organizacji politycznych. W 1904 r. został wraz z Aleksandrem Świętochowskim współzałożycielem Stronnictwa Postępowo-Demokratycznego zwanego potocznie „Pedecją”, a w październiku 1905 r. brał udział w założycielskim zjeździe znanej rosyjskiej Partii Konstytucyjno-Demokratycznej tzw. "kadetów”. Już rok później, w 1906 r., Lednicki został z jej ramienia deputowanym do pierwszej Dumy jako poseł ziemi mińskiej. Mandat zdobył dzięki budowie szerokiej koalicji grup narodowych, w szczególności polskiej i żydowskiej, oraz rosyjskich liberałów. Jako poseł realizował program obrony interesów wszystkich mniejszości narodowych Rosji, co naraziło go na krytyki ze strony endecji za brak pełnego oddania dla sprawy polskiej. W Dumie utworzył „Grupę Parlamentarną Terytoriów Zachodnich", która jednoczyć miała nie-rosyjskich posłów z Kresów oraz "Związek Autonomistów i Federalistów” będący frakcją działającą na rzecz równouprawnienia obywateli Rosji niezależnie od ich narodowości. Budował w ich ramach koalicję z Żydami oraz innymi mniejszościami narodowymi Imperium, w szczególności narodami bałtyckimi i kaukaskimi, oraz rosyjskimi liberałami i demokratami zjednoczonymi przeciw obozowi konserwatywno-rządowemu. W domu Lednickiego w Moskwie przy zaułku Kriwonikolskim odbywały się m.in. zjazdy działaczy kadeckich, łącznie z założycielskim, a także liczne spotkania Polaków różnych orientacji z liberałami rosyjskimi. Uczestniczyło w nich szerokie spektrum polskich polityków i intelektualistów, m.in. Marian Zdziechowski i Roman Dmowski. W kwietniu 1905 r. w domu Lednickiego odbył się głośny "Zjazd Polsko-Rosyjski", którego główną ideą było stopniowe "oswajanie" liberałów rosyjskich z ideą polskiej autonomii w ramach Imperium. Wśród polskich partnerów Lednickiego byli początkowo tzw. "realiści”, w tym Liga Narodowa Dmowskiego. Sam Dmowski z czasem przeszedł na pozycje dialogu z Mikołajem II i jego rządem, odchodząc od bliskiej środowiskom Lednickiego idei pogłębiania współpracy z rosyjskim obozem liberalnym. Warto jednak wspomnieć, że współpraca owa nie była łatwa nawet dla samego Lednickiego. W kryzysowym jej momencie doznał tak znaczącego rozczarowania zdystansowanym stosunkiem rosyjskich liberałów wobec polskich postulatów samodzielności narodowej, iż wystąpił z partii Kadetów, deklarując, że ich polityka jest sprzeczna z polską racją stanu. Ruch ten nie spowodował jednak zerwania jego współpracy z rosyjskimi środowiskami liberalnymi, był raczej próbą wywarcia na nie nacisku oraz utrzymania uznania dla swej roli gtównego reprezentanta interesów narodowych w coraz bardziej radykalizującej się społeczności polskiej. W okresie coraz bardziej narastających emocji na tle narodowym i idących coraz dalej żądań kolejnych grup narodowych Imperium pozycja Lednickiego, próbującego opierać się na jak najszerszym spektrum środowisk polskich oraz utrzymywać konstruktywny dialog z rosyjskimi liberałami, stawała się z czasem coraz trudniejsza. Ostatecznie w wyniku rozpadu dawnej Rosji Led- 
nicki utracił swój status, ale jak się wydaje, w ciągu kilkunastu lat poprzedzających upadek Imperium odgrywał on w Rosji znaczącą, a dziś w znacznym stopniu zapomnianą, rolę kulturową i polityczną, której istotnym elementem było swoiste stopniowe oswajanie Rosjan z kwestią polską i integracja społeczności polskiej.

Znakomitą ilustracją napięć, w sercu których znalazł się w tym okresie Lednicki, jest krytyka polskiej reprezentacji w Pierwszej Dumie, jaką sformułował w ówczesnym okresie Władysław Studnicki - przedstawiciel opcji proniemieckiej, a jednocześnie klasyczny reprezentant środowisk inteligenckich. W jego emocjonalnych słowach, które przytaczam tu za Ludwikiem Bazylowem (1984: 363) wydaje się dobrze ujawniać napięcie nie tylko odnoszące się do strategii wobec Imperium Rosyjskiego, ale przede wszystkim zdefiniowane w wymiarze konfrontacji pomiędzy elitami kapitału ekonomicznego i kulturowego.

Pisał więc Studnicki o polskich posłach tak:

„Oni to pracują nad unicestwieniem polskości w rodzinnych stronach, pracując nad zacieraniem jej świadomości. Litwa i Ruś ... głosowały za tymi, których dawnymi czasy obierano na marszałków ze względu na dobrą kuchnię. Stąd wśród postów znaleźli się: hr. Józef Potocki, znany z milionowych przegranych w karty i polowań egzotycznych; 'kataryniarz', zaprzaniec, znany z manifestacji lojalistycznych hr. Milewski ... Lednicki, Rosjanin, pochodzenia polskiego, agent kadetów do spraw polskich ... biskup Ropp - ach, gdyżbym zapomniał, że jest biskupem ... musiał zawsze dodać coś religijnego, religijności wrodzonej nie miał, więc dawał coś robionego" (Studnicki, 1907: 10-11).

Tymczasem w czasie I wojny światowej Lednicki zaangażował się w organizację akcji ratunkowej Polaków na Wschodzie, stając na czele Polskiego Komitetu Pomocy Ofiarom Wojny. Po rewolucji lutowej 1917 r. stanął na czele Komisji Likwidacyjnej do spraw Królestwa Polskiego, powołanej przy Rządzie Tymczasowym księcia Lwowa, później Kiereńskiego. W komisji posiadał uprawnienia ministra Rządu Tymczasowego. Po zniesieniu Komisji przez Bolszewików² działał krótko jako przedstawiciel Rady Regencyjnej przy rządzie sowieckim, próbując przede wszystkim ratować niezliczonych Polaków z rąk CzeKa, pomagać w ewakuacji ludzi, ale co znamienne także i mienia oraz kapitałów do Polski. Wcześniej Lednicki odmówił uznania Komitetu Narodowego Polskiego w Paryżu pod przewodnictwem Romana Dmowskiego, co spowodowało, że członkowie Narodowej Demokracji opuścili kierowaną przez Lednickiego Komisję Likwidacyjną. Lednicki był przeciwnikiem tworzenia w Rosji armii polskiej, która miałaby walczyć z Niemcami, za co był szczególnie silnie krytykowany. Stanowisko jego było zgodne z polityką Rządu Tymczasowego bojącego się powstawania na terenie Rosji armii narodowych, a sprzeczne z oczekiwaniami aliantów zachodnich, u których Lednicki nie znalazł w związku z tym uznania, które zdobył natomiast w tym czasie już o wiele bardziej radykalny Roman Dmowski.

Na początku 1918 r. Lednicki wyjechał z Moskwy na konsultacje do Warszawy, z której już do Rosji nie wrócit, jako że przedstawicielstwo Rady Regencyjnej, którym kierował, zostało przez Bolszewików rozwiązane, a jego personel w większości aresztowany. W niepodległej Polsce Lednickiemu nie udało się wejść do głównego nurtu polityki odrodzonego Państwa Polskiego. Jego środowisko polityczne przestało de facto istnieć, a on sam postrzegany był za zbyt "rosyjskiego”. Jego kilkukrotne próby włączenia się w życie publiczne kończyły się niepowodzeniem lub bardzo nieznaczącymi efektami. W latach 19191923 wydawał na przykład w Warszawie tygodnik „Tydzień Polski” propagujący paneuropeizm i popierający uznanie niepodległości Litwy, Łotwy, Estonii, Finlandii i Gruzji. Działał

\footnotetext{
2 Formalnie Komisja została włączona do będącego częścią składową Narodowego Komisariatu do Spraw Narodowych Komisariatu do Spraw Polskich kierowanego przez Juliana Leszczyńskiego-Leńskiego.
} 
też w ramach Związku Obrony Mienia Polaków Poszkodowanych w Rosji oraz utrzymywał kontakty z pozostającymi w Polsce emigrantami z Rosji Bolszewickiej. Zaangażował się jednocześnie w działalność gospodarczą, której kluczowym wymiarem stała się obsługa kapitału zachodniego. W szczególności został prezesem Banku Polsko-Amerykańskiego oraz Towarzystwa Przyjaciół Elektryfikacji Polski im. Gabriela Narutowicza założonego przez Przemysława Podgórskiego. Instytucje te utworzyły Polsko-Amerykańską Spółkę Akcyjną Elektryfikacji Polski. W dniu 11 sierpnia 1934 r. popełnił samobójstwo w związku z oskarżeniami wysuwanymi wobec niego o reprezentowanie obcych interesów w głośnym wówczas polsko-francuskim sporze o inwestycje w Żyrardowie, który zakończył się nacjonalizacją znanych zakładów Inianych. Ich historia sama w sobie jest również dobrą ilustracją rozwoju kapitalizmu na ziemiach polskich. Odbudowane po I wojnie światowej, zostały w 1923 r. sprzedane spółce francuskiej znacznie poniżej kosztów ich rekonstrukcji. Nacjonalizacja przeprowadzona w 1934 r. miała w zamierzeniu zademonstrować asertywność Państwa Polskiego wobec kapitału zagranicznego, który jednak już wtedy kontrolował znaczną część polskiego przemysłu.

Podsumowując, zauważyć można, że wypieranie Lednickiego i wielu innych znaczących w historii Polski osób z podobnych środowisk ze świadomości publicznej, a następnie dyskursu historycznego rozpoczęło się już za jego życia, w okresie powstawania II Rzeczypospolitej. Świadomość tego faktu przyjmował z resztą sam Lednicki bardzo boleśnie, o czym szczególnie wyraziście pisze jego syn Wacław w swoich pamiętnikach (Lednicki 1963). Wspominał on o sobie, swym ojcu i ich środowisku jako ludziach, których świat zawalit się w 1918 r., a ostatecznie przestał istnieć w roku 1944. Stali się oni, jak pisał Wacław Lednicki, „ludźmi bez tła”. „Tło” owo współcześnie, warto zauważyć, nie tylko od dawna już nie istnieje, ale zostało w dużym stopniu wyparte z pamięci społecznej.

\section{WOJNA POLSKO-BOLSZEWICKA A LOS POLSKIEGO OBOZU LIBERALNEGO}

Wskazując na kluczową rolę rewolucji październikowej 1917 r. w procesie marginalizacji elity kapitału ekonomicznego w polskim polu władzy i związanym z nim unicestwieniem ówczesnego obozu liberalnego, warto przypomnieć o polskiej roli w procesie upadku Imperium Rosyjskiego. W szczególności w tym kontekście przypomnieć można, że przechylenie się w wojnie domowej w Rosji szali na korzyść bolszewików nie odbyło się bez udziału zdominowanych już przez obóz inteligencji elit polskich. Jak przypomina o tym szczególnie emocjonalnie Józef Mackiewicz (Mackiewicz 2007/1962), kluczowym momentem były tu rozmowy polsko-bolszewickie w Miklaszewiczach pod Łuckiem w październiku i listopadzie 1919 r. Podjęta w tym okresie przez Józefa Piłsudskiego decyzja o odmowie wsparcia wojsk białych pod dowództwem Denikina miała dalekosiężne skutki dla losu obu krajów i całego regionu, a nawet kontynentu. Może ona być rozpatrywana jako opowiedzenie się za wrogiem postrzeganym za wygodniejszego; zarówno ze względu na jego słabość jak i negatywną reputację wśród mocarstw zachodnich. Mackiewicz przytacza słowa Piłsudskiego, który deklarował otwarcie, iż

„współpraca z Denikinem w jego walce z bolszewikami nie odpowiada polskim interesom państwowym (...) Podstawą polityki naczelnika Państwa Polskiego jest fakt, że nie chce dopuścić, aby rosyjska reakcja zatriumfowała w Rosji. I dlatego będzie on robić wszystko, by do tego nie dopuścić" (za: Mackiewicz 2007/1962: 82). 
Warto zwrócić uwagę, że rozumowanie to jest oparte na założeniu, iż jedyną alternatywą dla Rosji komunistycznej jest Rosja konserwatywna, równie autorytarna i ekspansywna, ale groźniejsza dla Polski ze względu na swój status na Zachodzie. Piłsudski wyraźnie nie bierze więc pod uwage możliwości liberalnych reform w Rosji, a jednocześnie wydaje się nie dostrzegać kosztów związanych z załamaniem się systemu gospodarczego tego kraju dla Polski. Postawę tę można wiązać nie tylko z jego lewicową orientacją polityczną, ale także z lokalizacją w ówczesnym polu władzy na pozycjach ściśle inteligenckich, wypierających ze świadomości rolę kapitału ekonomicznego, a sakralizujących znaczenie narodowo zdefiniowanego kapitału kulturowego. Piłsudski wybiera więc jako oponenta pozbawioną zachodniego poparcia Rosję Bolszewicką, którą udało mu się rzeczywiście wkrótce pokonać w bezpośredniej konfrontacji. Niemniej jednak wojna polsko-bolszewicka doprowadziła, jak wiadomo, w pewnym momencie do ryzyka ponownego upadku Polski i wprowadzenia w niej ładu komunistycznego już w 1920 r. Ta groźba została oddalona dzięki tzw. Cudowi nad Wisłą. Jednak już 19 lat później wojska bolszewickie zajęły w porozumieniu z Hitlerem połowę ówczesnej Polski, doszło m.in. do Masakry Katyńskiej i wielu innych zbrodni, które w świetle polityki uprawianej przez bolszewików od pierwszych dni objęcia przez nich władzy w Rosji nie powinny być jednak uważane za coś zaskakującego. O zagrożeniach tych wielokrotnie wspominał w okresie międzywojennym Marian Zdziechowski, jednak jego głos nie był chętnie słuchany, a ostrzeżenia lekceważone i wyciszane ze względu na postrzeganie ich jako niekorzystnych dla atmosfery stosunków polsko-sowieckich (Zdziechowski 1938). Należy także podkreślić, iż w wyniku wspomnianych wydarzeń nie tylko przestało istnieć państwo polskie, ale na terenach zajętych przez Związek Sowiecki, które w 1945 r. objęły całość ziem polskich, przestała także funkcjonować poważniejsza własność prywatna. Jak uważał Józef Mackiewicz, Piłsudski nie przyjmował do wiadomości, iż wojna z bolszewikami to nie "konflikt pomiędzy państwami, lecz integralna walka z ustrojem kapitalistycznym wszystkich to państw świata" (Mackiewicz 2007/1962: 87) a także iż "sprawa granic państwowych jest dla komunistów rzeczą w praktyce podrzędną, bądź wygrywaną jedynie dla celów taktycznych" (Mackiewicz 2007/1962: 92). Pokój ryski 1921 r., pozwalający na funkcjonowanie Polsce przez kilkanaście lat, nie tylko nie zapewnił krajowi długotrwałego bezpieczeństwa, ale doprowadził wkrótce do likwidacji kapitalistycznych stosunków własności na terenie kraju aż do około 1989 r. Fakt ten oznaczał, że jedynym dysponentem większości majątku stały się władze polityczne ściśle podporządkowane Moskwie. Na cały ten okres Polacy stracili więc możliwość nie tylko akumulacji, ale i zasadniczo posiadania realnego kapitału ekonomicznego, w szczególności finansowego. W całym regionie Europy w momencie upadku systemu powstała sytuacja, którą József Böröcz (Böröcz 1992) nazwał „próżnią własnościową". Próżnia ta została z czasem zapełniona w większości przez kapitał zachodni, a przed mieszkańcami Polski zarysowała się perspektywa pierwotnej akumulacji kapitału z zerowego zwykle punktu wyjścia. Uwarunkowania te spowodowały, że zasoby ekonomiczne polskich przedsiębiorców są dziś ciągle relatywnie małe, a pozycja kraju w wymiarze gospodarczym słabsza od większości krajów zachodnich o podobnych rozmiarach i ludności.

Jak się wydaje, można argumentować, że jest to jedna z cen, jaką Polska zapłaciła za decyzję Piłsudskiego o poparciu bolszewików w 1919 r. Może ona być rozpatrywana jako zwycięstwo myślenia w kategoriach granic politycznych, a więc kapitału politycznego i kulturowego, nad myśleniem w kategoriach praw własności, a więc kapitału ekonomicznego. Wybierając ofertę Lenina kosztem oferty Denikina, Józef Piłsudski skazywał, być 
może nie w pełni świadomie, pozostałych w granicach Rosji przeobrażającej się w Związek Sowiecki Polaków na pozbawienie ich wszelkiego majątku, utratę jakichkolwiek praw politycznych, wielu zaś wcześniej czy później na nieszczęśliwą egzystencję materialną zakończoną nierzadko tragiczną śmiercią. Ci z nich, którzy ocaleli, znajdując możliwość ucieczki do Polski, tak jak Lednicki i wielu innych reprezentantów jego wpływowego kiedyś środowiska, utracili, jak wspomniano, większość swych kapitałów, zarówno ekonomicznych jak i politycznych. Należy zwrócić uwagę, że była to katastrofa nie tylko osobista grupy osób posiadających znaczniejsze majątki. Składały się one bowiem na majątek społeczności polskiej, który umożliwiał jej realizację istotnych interesów społecznych, gospodarczych czy politycznych. Warto wspomnieć, że szeroko rozumiane polskie aktywa w Rosji to nie tylko majątki ziemskie, ale także nieruchomości miejskie oraz udziały w wielu przedsiębiorstwach, często firmach kapitałowych, w dynamicznie rozwijającej się na początku XX w. Rosji. Znamiennym przykładem środowiska zdegradowanych wówczas dawnych elit ekonomicznych jest głos Zdzisława Grocholskiego (1929), przewodniczącego „Koła Polaków Ziem Ruskich”, zrzeszających dawnych właścicieli ziemskich z terenów przekazanych Związkowi Sowieckiemu. Grocholski przedstawia w swojej broszurze specyficzną krytykę traktatu ryskiego niekorespondującą już z inteligencką logiką dominacji kapitału kulturowego i służącemu mu kapitału politycznego. Wyraża bowiem przekonanie, że sam przebieg granicy politycznej między Polską a ZSRR wyznaczony w traktacie ma znaczenie wtórne w stosunku do zgody na nacjonalizację majątku przez władze sowieckie, zgodę na co przedstawicieli Polski uważa za zdradę.

Marginalizowanie znaczenia roli kapitału ekonomicznego w definiowaniu interesów narodowych wydaje się być trwającą po dzień dzisiejszych cechą polskich dyskursów politycznych zdominowanych przez elity inteligenckie. Warto tymczasem zauważyć, że sam Lednicki jest przykładem człowieka, który dzięki majątkowi własnemu oraz możliwości zmobilizowania zasobów związanych z nim Polaków w Rosji był w stanie podejmować istotne z punktu widzenia interesów polskich przedsięwzięcia. Były nimi wspomniane powyżej stowarzyszenia społeczne i dobroczynne, budowa kościołów katolickich (na czele z kościołem Nawiedzenia Najświętszej Maryi Panny w Moskwie, którego budowę Lednicki w dużym stopniu koordynował osobiście oraz częściowo finansował) i budynków użyteczności społecznej. Był on nie tylko w stanie wspierać materialnie licznych Polaków, w szczególności działaczy w sferach kulturowej, politycznej i gospodarczej, ale finansował też przedsięwzięcia oświatowe, m.in. wydawnicze, w różnych częściach Rosji i ziem polskich. Przykładem jego zdolności kapitałowych i inicjatywy była powzięta przez niego inicjatywa sfinansowania katedry na University of London, którą zająć miał Marian Zdziechowski. Ten niezrealizowany projekt pokazuje zdolności finansowe diaspory, kontrastujące wymownie z współczesną niemocą Polski w zakresie finansowania katedr polskich na znanych zachodnich uniwersytetach. I tak, na przykład, zbiórka funduszy na jednoosobową katedrę polską na uniwersytecie Columbia w Nowym Jorku trwała kilka lat i wymagała zmobilizowania wielu agend państwa polskiego oraz licznych przedsiębiorców. Wspomnijmy, że osób majętnych w Rosji poczuwających się do obowiązku inwestowania w instytucje publiczne działające na rzecz społeczności polskiej, było wiele. Wspomnieć można tu choćby bankierów Wawelberga, Rotwanda czy Kronenberga. Im zawdzięczamy m.in. powstanie ważnych instytucji edukacyjnych. Fundacja Mianowskiego dzięki darowiźnie polskiego inżyniera pracującego w Rosji - Witolda Zglenickiego dysponowała polami naftowymi w Baku dostarczającymi kapitałów przewyższających możliwości wydania ich ówcześnie na cele statutowe, to jest wspieranie polskiej nauki. Można zauważyć, że być 
może w jakimś stopniu także w efekcie decyzji Piłsudskiego o wsparciu Lenina kosztem Denikina wszystkie te zasoby znajdujące się w rękach polskich przepadły w większości już około 1918 r. Przepadek większej polskiej własności prywatnej jako takiej dokonał się ostatecznie pod koniec lat 40. XX w.

Od logiki ekonomicznej nie mniej ważna w analizowaniu omawianych procesów wydaje się logika geopolityczna, której elementem jest upadek Imperium Rosyjskiego jako relatywnie równorzędnego w stosunku do krajów zachodnich gracza na scenie europejskiej. Nawet po upadku Związku Sowieckiego, odrodzona Rosja nie zdecydowała się na jednoznaczne nawiązanie do tradycji Rosji przedkomunistycznej, a jej władze, szczególnie od końca lat 90. XX w., coraz bardziej definiowały swą tożsamość jako antyeuropejską. Jak argumentowałem już wcześniej (Zarycki 2012), można przypuszczać, że te czynniki oraz generalna słabość Rosji, przede wszystkim gospodarcza, całkowite jej uzależnienie od eksportu paliw kopalnych, powodują, że odnoszenie się do historii kontaktów z Rosją pozostaje od 1918 r. trudne. Zdegradowana ekonomicznie i symbolicznie Rosja nie jest bowiem atrakcyjnym punktem odniesienia dla współczesnych narracji tożsamościowych. Efektem tego stanu rzecz jest, jak się wydaje, nieproporcjonalna dziś deprecjacja Polaków zaangażowanych w życie polityczne Rosji carskiej w stosunku do osób zaangażowanych podobnie $w$ instytucjach pozostałych państw zaborczych. Ta dominująca dziś interpretacja jest znacząco odmienna od przeważających ocen moralnych do 1918 r. (Chwalba 1999). Powoduje także, że dominujące współcześnie stereotypy zaboru rosyjskiego są nieporównywalnie z sytuacją sprzed 100 lat niekorzystne w stosunku do funkcjonujących dziś stereotypów na temat zaboru austriackiego i pruskiego (Zarycki 2009). Jednocześnie zarówno w Rosji, jak i poza jej granicami, dominuje dość jednostronna pamięć o jej przedrewolucyjnej historii. W Polsce w dużym stopniu z pamięci wyparto rolę zaangażowanych społecznie Polaków w Imperium Rosyjskim do rewolucji bolszewickiej 1917 r. Wacław Lednicki, syn Aleksandra, wspomina iż jego ojciec próbował w pierwszych latach po odzyskaniu niepodległości przez Polskę w 1918 r. doprowadzić do odznaczenia szeregu uchodźców z dalekich Kresów, głównie ziemian, którzy w głębi Rosji prowadzili rozliczne inicjatywy wspierające polskość w Imperium (Lednicki 1963). Według relacji Wacława Lednickiego, do odznaczeń tych nie udało się doprowadzić, prawdopodobnie także ze względu na eliminację z międzywojennego pola politycznego przeszłości polskich ruchów społecznych działających w Rosji, a niezaangażowanych ani w ramach endecji, ani kręgach PPS. Środowiska te okazały się jeszcze mniej wygodne dla rządzących w PRL. Przypominanie o ich istnieniu byłoby jednoznaczne z szerzeniem wiedzy o całkiem innej Rosji od prezentowanej w oficjalnej historiografii, a także wskrzeszaniem pamięci o roli niekomunistycznych działaczy społecznych i politycznych szukających dróg porozumienia z Rosjanami na płaszczyznach całkowicie odmiennych od komunistycznej.

\section{PRZESTRZEŃ MIEJSKA A PAMIĘĆ O MOSKIEWSKICH POLAKACH}

Warto zwrócić uwagę, że wymownym przejawem zniknięcie z pamięci społecznej Aleksandra Lednickiego i jego środowiska jest przestrzeń symboliczna miast rosyjskich. Jednymi z najbardziej widocznych śladów pozostawionych przez Polaków w krajobrazie wielu rosyjskich miast są kościoły katolickie. Budowane były w wielu przypadkach przede wszystkim dzięki inicjatywie i funduszom społeczności polskich. Ich projektantami byli też 
często Polacy, w szczególności Tomasz Bohdanowicz-Dworzecki, autor projektu neogotyckiego kościoła, a dziś katedry Niepokalanego Poczęcia Najświętszej Marii Panny w Moskwie przy ulicy Mała Gruzińska czy też kościoła Najświętszego Serca Pana Jezusa w Samarze. W okresie komunistycznym wszystkie katolickie świątynie w Rosji, poza dwoma kościołami, jednym w Moskwie i jednym w ówczesnym Leningradzie, zostały zamknięte, a część całkowicie zniszczono. W ostatnich latach wiele z nich zostało przywróconych do swoich funkcji, jednak pamięć o środowiskach, które świątynie te wznosiły, prawie całkowicie zanikła, tym bardziej że służą dziś zwykle miejscowym społecznościom katolickim, w których Polacy mają już znacznie mniejszy udział. Jednak najbardziej chyba spektakularnym przykładem urwania się pamięci o korzeniach społecznej przestrzeni miast Rosji jest pałacyk Aleksandra Lednickiego w Moskwie przy Kriwonikolski Pierieutek 8. Co ciekawe, jego przebudowami na potrzeby właściciela kierował także wspomniany już Tomasz Bohdanowicz-Dworzecki. Jak pisze Zenowiusz Ponarski (Ponarski 2003), w pałacyku wyróżniał się piękny salon o 9 ogromnych oknach, znany w historii jako „salon Lednickiego”. To mogące pomieścić z górą 200 osób pomieszczenie było miejscem spotkań polsko-rosyjskich, włączywszy wspomniane powyżej zjazdy oraz szereg innych zebrań i wydarzeń kulturalnych, politycznych i towarzyskich. Dom Lednickiego został po likwidacji przedstawicielstwa Rady Regencyjnej przydzielony przez władze sowieckie polskim komunistom. Pamięć o tym, kto był jego wcześniejszym właścicielem i w jaki sposób był on wcześniej związany z losami Polski, szybko jednak zanikła. Interesującego świadectwa na ten temat dostarcza mieszkająca obecnie w Polsce profesor Swietłana Czerwonna, która jako dziecko dorastała w dawnym domu Lednickiego. Co znamienne, w świadomości tej zainteresowanej historią domu swojego dzieciństwa uczonej do niedawna nie istniała żadna wiedza o jego przeszłości. Można na tej podstawie przypuszczać, że pozbawione było jej już pokolenie jej rodziców bądź w warunkach komunistycznego terroru bało się ową wiedze przekazywać młodszym. Oto, co pisze o domu Lednickiego sama Czerwonna:

„Już w latach 20. dom ten został przeznaczony na mieszkania dla członków polsko-litewskiej sekcji Kominternu, miały w nim mieszkać rodziny pozostałych w Rosji Radzieckiej weteranów Socjaldemokracji Królestwa Polskiego i Litwy. Do lat 30. wszyscy ci weterani SDKPiL byli już członkami WKP(b). Niestety nie mam możliwości powołania się na materiały archiwalne, mogące potwierdzić i uściślić wszystkie okoliczności tego, że dom na zaułku Kriwonikolskim 8 stat się taką polską rezydencją" (Czerwonna 2004: 64).

I dalej:

„W tym domu mieszkało wiele osób. Prawdopodobnie w przeszłości jego główna część (kamienna trzypiętrowa budowla) była domem 'dochodowym', przy czym apartamenty, na które składała się amfilada pomieszczeń całego jednego piętra, były przeznaczone dla zamożnych najemców. O ich stylu życia mogły świadczyć pozostałości wspaniałych wnętrz pierwszego piętra: znajdowała się tam okrągła lub owalna sala, otoczona kolumnami; o dawnym przepychu świadczyły też duże okna, parkiety, wysokie sufity, a w kilku mieszkaniach balkony. Za naszych czasów każdą z czterech kondygnacji zamieniono na wspólne ('komunalne') mieszkania z korytarzami pośrodku, sala kolumnowa została podzielona ściankami na kilka mieszkań (w jednym z nich mieszkała rodzina Sokolskich, u których często w dzieciństwie bywałam i zawsze z ciekawością patrzyłam na kapitele kolumn, ginące gdzieś za przepierzeniem linie attyki i stopnie schodów, prowadzące od drzwi w dół - do dawnej sali balowej)" (Czerwonna 2004: 65).

Czerwonna w swoim tekście o pałacyku Lednickiego zamieszcza szereg tragicznych historii zamieszkałych w nim rodzin. Od lat 30. ubywało w nim Polaków, na początku z powodu masowych aresztowań w czasie Wielkiego Terroru, potem repatriacji, a następ- 
nie asymilacji związanej z tendencją do zacierania polskiego pochodzenia jako będącego w ZSRR obciążeniem mogącym utrudniać karierę. Wcześniejszych mieszkańców zajmowanego przez jej rodzinę mieszkania aresztowano za śpiewanie polskich piosenek na urodzinach, ich dzieci wysłano zaś do sierocińca. Sam dom zburzono na początku lat 60. XX wieku w związku z wytyczaniem wielkiego „prospektu Kalinina” zwanego obecnie "Nowym Arbatem". Pozostał po nim jedynie fragment oficyny na zapleczu wieżowców stojących przy Nowym Arbacie. Warto zwrócić uwage, że o tym i wielu innych polskich śladach w Moskwie z okresu przedrewolucyjnego nie pamiętają nawet autorzy piszący przewodniki mające w zamierzeniu uwzględniać właśnie polskie wątki w przestrzeni tego miasta.

Jak się wydaje, los Aleksandra Lednickiego i bliskich mu zaangażowanych społecznie i politycznie środowisk polskich w Imperium Rosyjskim wart jest uwagi z wielu powodów. Po pierwsze, jak starałem się pokazać, ilustrują one znakomicie kluczową ewolucję polskiego pola władzy, której owocem jest trwająca w nim po dzień dzisiejszy przewaga kapitału kulturowego nad ekonomicznym oraz trwała dominacja elity inteligenckiej jako jedynej grupy zdolnej do wielopokoleniowej reprodukcji i utrzymania swojego uprzywilejowanego statusu w polu władzy. Takie uwzględniające historię marginalizacji kapitału ekonomicznego i jego posiadaczy spojrzenie na genezę polskich elit wydaje się także pomagać w zrozumieniu wielu cech charakterystycznych współczesnej polskiej inteligencji. Jednocześnie biografie Lednickiego i osób ze wspomnianych środowisk pozwalają na spojrzenie na historię Rosji oraz stosunków polsko-rosyjskich w sposób odmienny od dominujących dziś paradygmatów. W szczególności pozwalają zwrócić uwagę na arbitralny charakter wielu przyjętych powszechnie interpretacji oraz cech przypisywanych Rosji i jej społeczeństwu. Dają też dodatkowy wgląd w historię społeczną i polityczną Polski i wskazują na jej uzależnienie od pozycji Rosji w systemie światowym. Przyglądając się opisywanym tu środowiskom w szerszym kontekście przemian społeczno-politycznych, można także uzyskać lepszy wgląd w genezę tożsamości nielicznych grup kultywujących pamięć o utraconych pomiędzy 1917 a 1944 r. kapitałach ekonomicznych. Należy do nich w szczególności środowisko postziemiańskie, którego spadkobiercy tworzą co prawda niewielkie, ale wciąż żywe i relatywnie wyodrębnione środowisko społeczne (Smoczyński, Zarycki, 2012).

LITERATURA

Bazylow, Ludwik (1984) Polacy w Petersburgu. Wrocław: Zakład Narodowy im. Ossolińskich.

Böröcz, József (1992) 'Dual Dependency and Property Vaccum: Social Change on the State Socialist Semiperiphery', Theory and Society, 21 (1), s. 77-104.

Bourdieu, Pierre (1986) 'The Forms of Capital', (w:) J.G.Richardson (ed.), Handbook of Theory and Research for Sociology of Education, New York, Westport, Connecticut, London: Greenwood Press, s. 241-58. 
- (2006) Dystynkcja. Społeczna krytyka władzy sądzenia. Warszawa: Wydawnictwo Naukowe "Scholar", tłum. Piotr Biłos.

—, Loï J.D. Wacquant (1993) 'From Ruling Class to Field of Power: An Interview with Pierre Bourdieu on La Noblesse d'État', Theory, Culture \& Society, 10, s.19-44.

Chwalba, Andrzej (1999) Polacy w stużbie Moskali, Warszawa, Kraków: Wydawnictwo Naukowe PWN.

Czerwonna, Swietłana (2004), Kriwonikolskij 8 - Dom Polski', Zesłaniec. Pismo Rady Naukowej Zarządu Głównego Związku Sybiraków, 17, s. 63-79.

Grocholski, Zdzisław (1929) Kresowe Ziemie Ruskie Najjaśniejszej Rzeczypospolitej. Warszawa: Nakładem Koła Polaków Ziem Ruskich.

Kucharzewski, Jan (1923) Od biatego caratu do czerwonego, Warszawa: Wydawnictwo Kasy im. J. Mianowskiego.

Lednicki, Wacław (1963) Pamiętniki, tom I, Londyn: B. Świderski.

Mackiewicz, Józef (2007/1962) Zwycięstwo prowokacji, Londyn: Kontra.

Ponarski, Zenowiusz (2003) Wokót sprawy polskiej na Wschodzie, Toruń: Wydawnictwo Adam Marszatek.

Rybak, Agnieszka (2010) 'Trzeźwy bankier, pijany rechot historii', Rzeczpospolita, 27-28 lutego 2010, s.12.

Said, Edward W. (2005) Orientalizm, Poznań: Zysk, tłum. Monika Wyrwas-Wiśniewska.

Smoczyński, Rafał i Tomasz Zarycki (2012) 'Współczesne polskie elity postszlacheckie w kontekście europejskim', Kultura i Społeczeństwo 1/2012, s. 261-292.

Studnicki, Władysław (1907) Pierwsza Duma Państwowa i działalność naszych postów. Warszawa.

Tazbir, Janusz (2003) 'O czym się pisać nie godziło', Gazeta Wyborcza, 27 grudnia, 2003, s.16-17.

Wise, Andrew Kier (2003) Aleksander Lednicki. A Pole among Russians, a Russian among Poles. Polish-Russian reconciliation in the Revolution of 1905 (Boulder: East European Monographs).

Zarycki, Tomasz (2004) 'Uses of Russia: The role of Russia in the modern Polish national identity', East European Politics and Societies, 18 (4), s. 595-627.

- (2008a) Kapitał kulturowy. Inteligencja w Polsce i Rosji. Warszawa: Wydawnictwa Uniwersytetu Warszawskiego.

— (2008b) 'O jednostronnej wizji „Wschodu” w Polskiej tożsamości narodowej', (w:) Jan Szomburg (red.), Modernizacja Polski. Kody kulturowe i mity, Gdańsk: Instytut Badań nad Gospodarką Rynkową, s. 73-80.

- (2009) Peryferie. Nowe ujęcia relacji centro-peryferyjnych, Warszawa: Wydawnictwo Naukowe "Scholar".

- (2012) The embarrassing Russian connection: selective memory of the Russian heritage in contemporary Poland, (w:) R. Taras (red.) Russia's Identity in International Relations. Images, Perceptions, Misperceptions, London: Routledge, s. 133-148.

Zdziechowski, Marian (1938) W obliczu końca, Wilno: Wydawnictwo Stanisława Turskiego. 


\title{
ALEKSANDER LEDNICKI AND THE FATE OF HIS MILIEU OF THE POLISH COMMUNITY IN RUSSIA AT THE TURN OF THE 20 TH CENT. AS A MIRROR OF THE TRANSFORMATIONS OF THE POLISH FIELD OF POWER
}

\begin{abstract}
Summary
The paper deals with the phenomenon of waning memory of the Polish economic elite in the late Russian Empire. It is related to the disappearance of the memory of the liberal political movement of the Polish political scene before the First World War. Mechanisms of these processes of forgetting are related to the theory of Pierre Bourdieu, in particular it is argued that the liberal Polish elite of the Russian Empire could be defined as economic-capital-based elite. Its rivals, both socialists led by Piłsudski and National-Democrats led by Dmowski, classical intelligentsia figures, could be seen as leaders of the cultural capital-based elites. As it is argued, the intelligentsia was in many ways a benefactor of the Bolshevik Revolution, which deprived the Polish economic elite of most of their capitals and led to its political marginalization. In effect the intelligentsia was able to impose its values and social hierarchies on the modern Polish national identity, which ever since is defined in terms largely unrelated to the economic logic. These mechanisms privilege memory of the intellectual figures and freedom-fighters in the mainstream canons of Polish history. A closer look at the forgotten economic and political Polish elite of the late Russian Empire allows to point out to several arbitrary elements in the dominant readings of the Polish and Russian history in contemporary Poland. They are illustrated in the paper on the example of the biography of Aleksander Lednicki, a prominent politician and lawyer, leader of the Polish community in Moscow until 1918.
\end{abstract}

Keywords: Polish intelligentsia, Polish landowners, Polish bourgeoisie, Polish-Russian relations at the turn of the $20^{\text {th }}$ century 